\title{
The Reason Daniel is Adopted as Canon
}

\author{
Saya Lee \\ Dept. of General Education, Namseoul University, Cheonan 580-2302, Korea \\ isaiah37@naver.com
}

\begin{abstract}
Of the many apocalyptic works from the second century B.C. to the first century A.D., only the book of Daniel was chosen as the canon, and most of the other documents were reduced to apocryphal. Who divided it for what reason? What effect did apocalyptic literature have on decision making? Who decided the canon? Why only the book of Daniel was adopted as canon? The reason is found in the educational aspect of Daniel. The book of Daniel taught the Jews living in times of suffering "how to live" in the reality of suffering, and Law teachers and rabbis recognized the value of the canon in Daniel.
\end{abstract}

Keywords: Daniel, Old testament, Apocalyptic literature, Suffering, Prophecy

\section{Introduction}

Countless apocalyptic literature appeared in the Israeli community between 200 and 100 B.C., the peak of apocalyptic literature. Apocalypse is a means of conveying a secret or interpretation of history and the universe [1]. Apocalyptic literature is a big part of Christianity, as it is said that apocalyptic literature is the mother of Christian theology [2]. But only the Book of Daniel was included in the Old Testament canon of the vast apocalyptic literature that appeared at the time. This is the middle of the Old and New Testaments. Thus, the book of Daniel is the only book that gives the political, social, and religious background of the Old and New Testaments after Malachi. Therefore, the historical background and canonical study in Daniel is important not only for understanding the middle-age history between the Old and New Testament, but also for understanding how the canon was determined.

Of the numerous apocalyptic literary works of this period, only Daniel was chosen as the canon, and the rest of the other documents were sentenced to death because they were containing danger. Who would have judged this? Why did he judge this? Why was the only book of Daniel recognized in the canon of many apocalyptic literature?

\section{Daniel and his three friends}

The book of Daniel is a representative Apocalyptic literature of the Old Testament, written just before the Maccabean Revolt, when the Israelites were under extreme religious oppression (160 B.C.). In the second century B.C., the Jewish community was under religious persecution by the Greek Empire, and they needed a new revelation of when the end of the world would come. Faced with this situation, the author of the Book of Daniel tried to solve

Article History:

Received (October 8, 2019), Review Result (November 12, 2019), Accepted (December 28, 2019) 
the question of how to accept a new revelation about the end of the world [3]. In the Hebrew Scriptures, this book of Daniel is one of the Bible texts, but because of its content and volume is similar to the prophetic books, it is located after Ezekiel in the Old Testament. Under the Greek Empire's Antiochus Epiphanes (175-163 B.C.), when Israel's traditional religious life was contraindicated, the story of the Jewish people trying to defend their faith and religious life in the face of death was unfolded through the protagonist Daniel. He demonstrates the purity of faith and loyalty to God even in situations where religious traditions are difficult to keep.

Generally, Old Testament scholars divide the book of Daniel into two. The first half is chapters 1-6 in Daniel's third person, and the second half chapters 7-12 in Daniel's first person. The first half begins with the protagonists Daniel (=Beldshazzar) and his three friends Hananiah(=Sadrak), Mishael (=Massach), and Azariah(=Abednego) not to defile themselves with the king's food and wine in the palace of Babylon (Dan 1:8).

Daniel and his three friends tried not to violate the Jewish diet of the law because of the food and meat of the Gentiles. According to the food regulations of the Law, there are some foods that the Israelites should not be near. Why was Daniel and his friends rejected the king's food and wine, though not all meat and wine were unclean? The answer can be found in the phrase "I will not defile myself." There may have been thought that they could not only favor themselves while the captives who were brought together were suffering, but above all, the law forbade the food of the Gentiles. It is likely that the foods were either unclean animals that should not be eaten, bloody meat (Deut. 12: 20-25), or meat associated with idolatry. In the history of the middle-age history between Old and New Testaments, when the Gentiles put pork on God's altar, it began to develop a nationwide independence movement. Food made according to the biblical dietary regulations is called Kosher, and the Jewish-run restaurant obeys the Kosher food law.

Their efforts to preserve traditional beliefs refuse to bow down to idols made of gold, and are shown in the story of their being abandoned in a burning furnace. King Nebuchadnezzar set up an image of gold and made all people bow to it. At this time Shadrach, Meshach, and Abednego were accused of refusing to bow to idols, and the king threatened to burn them and kill them, but they refused to do so by calling on God (Dan 3:17-18). Eventually, they were thrown into the furnace seven times stronger than usual. The king's servants who carried it out were to be burned to death, but they were safe.

This miraculous story is reiterated in Chapter 6, the last chapter of the first half. While the story of three friends being saved in the furnace is set in the time of Nebuchadnezzar in Babylon, the empire is changed here to tell the story of King Darius of Persia. Daniel was one of the three provincial governors, appearing as the next most powerful man after the king (Dan 6:3). This appearance of Daniel reminds Joseph. Just as Joseph was sold as a slave at age 17 and became Prime Minister of Egypt at age 30, Daniel, a boy who was taken captive at the time of the first invasion of Judah by the Babylonian king Nebuchadnezzar, became Prime Governor in Persia which ruled the ancient Near East after Babylon.

Joseph and Daniel were similar in that they both became prime minister/governor in foreign lands, but Daniel's story differs from Joseph's in that there was a group of jealousy. Those envious of Daniel could not find any blemish in Daniel as a public official, and had to find another way to destroy him. They found the way out of Daniel's faith. They caused the king to make a statement that for a while no one should bow to anyone or god other than the king. Behind the king's record was a plot to kill Daniel. This indicates that Daniel's religious life was already known to many. Eventually, despite King Darius' stamping the decree, Daniel prayed to Jerusalem three times a day, according to Jewish religious practices. 
Daniel prayed 'even though he knew that the king had a seal on it'. Even though he knew that he could be thrown into a lion's den, he returned to his house and prayed and thanked him. He stood in a situation where all his efforts as captives in foreign lands could crumble in a moment and kept his tradition of faith, knowing he could lose his life. What is interesting about this story is that Daniel "knelt down and prayed three times a day to open the window to Jerusalem." The habit of the Jews praying three times a day was formed in captivity. As the temple collapsed, the Jews who went to live in captivity created a new tradition of daily prayer toward Jerusalem (1Kings 8:48-49). Psalm 55, also known as Solomon's prayer after the temple, actually shows the religious habits of the Jews praying to Jerusalem from the Gentile land in exile (Psalm 55:17).

The flow of the day here in the order of evening-morning-noon is due to the Jewish concept of seeing as one day from six o'clock in the evening to six o'clock in the next day. Gen 1:5). Daniel's prayer for thanks in all circumstances was also regularized and habitualized by kneeling prayer "three times a day". His prayer was so regular that the enemy could find it easily. Those who tried to kill Daniel did not call Daniel a Persian official but instead called the captive sons of Judah. This indirectly shows how great jealousy was for Daniel. Perhaps they were pleased to be able to remove Daniel, who was like an eyebrow. However, the incident began to unfold unexpectedly. Daniel was thrown into the den of the incident, but King Darius, who cared for Daniel, found Daniel alive the next morning. Daniel's enemies were thrown into the lions' den, with their families, and Darius the king of the Gentiles confessed the God of Israel as a true God (Dan 6:26-27). These miraculous stories emphasize the apocalyptic literary era of persecution and suffering, and the faithful faith that should not be changed even under such circumstances.

\section{Daniel as an apocalyptic literature}

The second half of Daniel's first-person appearance (chapters 7-12) reveals many of Daniel's visions and symbols of the kingdoms of the world and the kingdom of God. Here the author drew a timeline of history leading up to the end of the day. For example, he described the Babylonian, Mede, Persian, and Greek empires, which historically conquered the ancient Near East, with lions and bears with eagle wings, leopards, and terrible beasts with ten horns (Chapter 7). And the days of "one time, two times, half a time", "1290 days", "1335 days" (Dan 7:25-28; chapter 12) symbolize the impending end.

In the Old Testament, apocalyptic literature differs from earlier prophetic literature in several ways. The difference can be found first in the understanding of history. The prophets were confident that God's will would be realized through the earth's historical reality and circumstances. For them, history is the stage where such the will of God is unfolded. But the meaning of history became more ambiguous and the confidence in history diminished in the history of exile and the subsequent suffering that began with the destruction of Jerusalem. The place of life that could not be understood as the logic of human reason and faith continued. In other words, the tragic historical reality, the absurdity of wicked forces overwhelming good, and the hopelessness of all hope for history continued. Apocalyptic literature, which emerged as a way of proclaiming God's righteousness at this time, had a fundamentally pessimistic attitude toward history. In this pessimistic attitude, history only moved toward the end according to the timetable of God's staged historical process. There could be no orbital correction of history. All apocalyptic literature consistently spoke of an imminent end, and apocalyptic writers were always conscious that they were living in the last stages of history, the imminent end of time. 
In apocalyptic literature, however, regardless of repentance, history proceeds toward a fixed goal [4]. Apocalyptic literature also applies strict temporal dualism to time. For the prophets all histories are under the providence of God. So no matter how dark the present situation is, it is an aspect of God's work of salvation. But the pessimistic attitude of apocalyptic literature to history is different. The more serious the absurd situation, in which evil forces seemed to be suppressing the good, the deeper the hostile attitude toward history. The present history is a dark age ruled by evil forces, and the coming age is a time of light governed by God. Both prophetic literature and apocalyptic literature have something in common to say hope for the future. However, for the prophets, the end refers to the completion of the history of salvation, whereas the apocalyptic eschatology indicates that the ideal future is realized by the end of the history of the wicked powers and the cosmic new creation.

The author of the book of Daniel reports the existential crisis in the Jews through a history apocalypse in quasi prophecy. In other words, by prophesying events that have already existed historically as if they were going forward, they realized that the prophecies had been hit in the audience's past history and present life, and in conjunction with the actual prophecies of the future, it is making the audience believe.

The author proclaimed that all of this was an event in God's plan, telling the Jews who had come to a meeting of theology in the reality of the persecuted and dying suffering of God's chosen people. Make Sim clear to them and teach them how to live in this time of suffering and comfort their faith.

Only the book of apocalyptic literature was accepted in the canon as a sacred text. This is because the book of Daniel was not a book emphasizing loyalty to the teachings of the law and inspiring revolution or rebellion under the influence of Greek ideologies such as immortality and dualism. The Book of Daniel was a Jewish piety literature that educated the Jewish existence living in times of suffering. That is why the Pharisees and rabbis did not execute the book of Daniel, like the other apocalypse, but acknowledged its value as canon. After all, the book of Daniel was able to survive and adopted as canon even in the sentence of death for apocalyptic literatures.

Among the works of apocalyptic literature, there is only one book that is recognized by the Christianity today and used in worship. In 198 B.C., after the rule of Judea fell from the Ptolemy dynasty in Egypt to the Seleucus dynasty in the Syrian region, the king of Seleucus, Antiochus IV Epiphanes, enforced the Greekization policy and tried to remove Judaism. The book of Daniel was one of the books of apocalyptic literature at that time, with mythological and symbolic literary techniques, combined with skepticism about theology and eschatological temporal, fateful, and dualistic thoughts raised in Jewish society.

When Daniel was chosen as canon, there were already many books of apocalyptic literature besides Daniel, for example, the fourth Esther, Enoch, Jubilee, Moses' Ascension. In these texts, the political, social, and religious background of the second century B.C. to the first century A.D., which is found in the book of Daniel, is also shown, as well as the apocalyptic features of the book.

The book of Daniel was not in the same fate as other apocalyptic texts because it emphasizes loyalty to the teachings of the law [5]. The rabbis accepted Daniel as a canon, not as a Greek textbook that inspires revolution or rebellion, but as a wisdom book to educate the Jewish existence in a time of suffering, "how to live." So it was also included in the Kethubim. 
The author of the book of Daniel made Jews realize that all history and events are designed in God's design so that they could not lose confidence in God and realize the meaning of events even under the oppression of the heathen [6].

\section{Conclusion}

From a literary point of view, many visions of Daniel belong to apocalyptic literature, just like Revelation in the New Testament. Apocalyptic literature is written in the language of parables and symbols and deals with history, the end, and what happens before this end. The Great theme of the book of Daniel and Revelation will have encountered spirited reign of God. The interest of these two books is not in calculating and estimating the end times. Rather, it encourages readers to endure to the end, even under the oppression of the system against God, and to wait for God to save and triumph.

The book of Daniel is both apocalyptic and piety literature. The book was not about rejecting 'God's rule over history and the plan of salvation' for Jews who suffered through apocalyptic language with a background in space, supernatural, and eschatological judgment in time. Instead it taught them how to survive. The book also suggests that we should wait patiently and endure more than any political or religious revolution. History seems to be going in the wrong way, but it all convinces us that it is ultimately in God's hands [7]. Eventually, the Book of Daniel promised Jews in the land of Palestine in the mid-second century B.C.E. to never give up hope for God, no matter how dark the world was, and to educate the Jewish realm of suffering times "how to live" [8]. Other apocalyptic books were Greekized, expecting the eschatological future (immortality, messianic thought, etc.) to see reality negatively, leading the Jews to the revolution and eventually dismantling the Jews. The book of Daniel, however, made it possible to understand reality immediately and to rise from difficult reality through the historical apocalypse of similar prophecy [9]. Furthermore, It not only convinced that the time of suffering was soon to end, but answered the question of whether martyrs and warriors because of their faith could participate in the final salvation, and whether wicked men would be retaliated.

\section{References}

[1] C. Rowland, "The open heaven: a study of apocalyptic in Judaism and early Christianity," London: SPCK, pp.14, (1982)

[2] E. Kaesemann, "New testament questions of today," London: SCM Press, pp.11, (1969)

[3] Chon-Hun Pae, "The formation of the book of Daniel viewed from new revelation dispute," The Korean Journal of Old Testament Studies, Seoul: Kingdom Books, pp.73, (2019).

[4] P. D. Hanson, "The dawn of apocalyptic: the historical and sociological roots of Jewish eschatology," rev.ed., Philadelphia: Fortress, pp.11-12,16-19, (1979) DOI: 10.2307/1517322

[5] N. Porteous, "Daniel, Old testament library," SCM Press Ltd, pp.150, (1979)

[6] Collins, A. Y., "Crisis and chatharsis: the power of the apocalypse," Philadelphia: Westminster Press, pp.141143, (1984)

[7] J. J. Collins, "The apocalyptic imagination. an introduction to the Jewish matrix of Christianity," New York: Crossroad, pp.88-89, (1987)

[8] N. K. Gottwald, "The hebrew bible: a socio-literary introduction," Philadelphia: Fortress, pp.112, (1985)

[9] E. Lohse, “Umwelt des neuen testament,” Ergmzungsreihe: Göttingen, pp.46-68, (1988) 
The Reason Daniel is Adopted as Canon

This page is empty by intention. 